\title{
Physicochemical and Microbiological Quality of Springs in Kyambogo University Propinquity
}

\author{
Timothy Omara ${ }^{1,2,3^{*}}$, Winfred Nassazi1,4, Monica Adokorach1, Sarah Kagoya1 \\ ${ }^{1}$ Department of Chemistry, Faculty of Science, Kyambogo University, Kampala, Uganda \\ ${ }^{2}$ Department of Health Sciences, Unicaf University, Longacres, Lusaka, Zambia \\ ${ }^{3}$ Department of Quality Control, Quality Assurance and Product Development, AgroWays Uganda Limited, Jinja, Uganda \\ ${ }^{4}$ Department of Chemistry and Biochemistry, Moi University, Eldoret, Kenya \\ Email: *prof.timo2018@gmail.com,winnipeace15@gmail.com, admonica944@gmail.com, kagoyasara5@gmail.com
}

How to cite this paper: Omara, T., Nassazi, W., Adokorach, M. and Kagoya, S. (2019) Physicochemical and Microbiological Quality of Springs in Kyambogo University Propinquity. Open Access Library Journal, 6: e5100.

https://doi.org/10.4236/oalib.1105100

Received: December 7, 2018

Accepted: January 7, 2019

Published: January 10, 2019

Copyright $\odot 2019$ by author(s) and Open Access Library Inc.

This work is licensed under the Creative Commons Attribution International License (CC BY 4.0).

http://creativecommons.org/licenses/by/4.0/

\section{(c) (i) Open Access}

\begin{abstract}
The availability of usable water in an area is the first indication of its demonstrated ability to sustain life. In peri-urban areas, urbanites utilize water from springs and compete disapprovingly for it amongst themselves and with animals. The straggling populace and the compromised sanitation are deteriorating spring water sources. There is an urgent need to analyze springs to ascertain their bacteriological and physical quality for possible cross contaminations that may be of public health importance. This study evaluated the bacteriological and physical profile of water from three springs in Kyambogo University vicinity. Two weekly water samples from each spring for five weeks were obtained and analyzed. The physicochemical parameters (temperature, $\mathrm{pH}$, turbidity, electrical conductivity, chlorides and sulphates), total coliform and $E$. coli counts of the samples were determined. The mean temperature of the water samples from Katalina, Airport spring 1 and Airport spring 2 were $20.53^{\circ} \mathrm{C} \pm 1.2^{\circ} \mathrm{C}, 21.53^{\circ} \mathrm{C} \pm 0.60^{\circ} \mathrm{C}$ and $20.33^{\circ} \mathrm{C} \pm 1.62^{\circ} \mathrm{C}$ respectively. The corresponding statistical mean $\mathrm{pH}$ values were $5.33 \pm 0.25$, $6.30 \pm 0.10$ and $7.10 \pm 0.46$. All the springs were found to be microbiologically contaminated with total coliforms and $E$. coli above WHO permissible limits. Conclusively, water from the sampled springs are not safe for drinking and the immediate strategy is to boil or treat the water before drinking. Drainage ditches should be constructed uphill of the springs to divert torrential flowing rain water which carry contaminants washed from Kyambogo hill.
\end{abstract}

\section{Subject Areas}

Analytical Chemistry, Environmental Chemistry

\section{Keywords}

pH, Temperature, Conductivity, Total Coliforms, Escherichia coli, Sanitary 
Risk Score

\section{Introduction}

Water is one of the fortuitous liquids that exists in all the three distinct states of matter: solid, liquid and gas. It is one of the most abundant, deceptive and indispensable resources for life on planet earth that is often prodigiously polluted [1]. The value derived from water rests on its quality for the envisioned purpose. Unsafe water is a world imminent health danger of daily increasing importance, as it is a milieu for a myriad of diarrheagenic microbes, chemical and radiological hazards [2]. Thus, the availability of sufficiently clean and microbially safe water according to WHO report [3] is of paramount importance as it confers appreciable health benefits to man. Water, including bottled water, have an imperfect world record in Portugal and Spain linked to typhoid and cholera [4] [5] [6] [7].

Kyambogo University (KYU), Uganda's second largest degree-awarding institution of higher learning is situated in a sub-urban area (Kyambogo), East of urbanite Kampala on Kyambogo Hill, 1240 meters above sea level. It is bordered by Kiwatule to the North, Banda to the East, Kinawataka to the South East, Mbuya to the South, Nakawa to the Southwest, Ntinda to the West and Northwest [8]. The geographical coordinates of Kyambogo are $0^{\circ} 20^{\prime} 54.0^{\prime \prime} \mathrm{N} 32^{\circ} 37^{\prime} 49.0^{\prime \prime} \mathrm{E}$; that is latitude 0.348334 and longitude 32.630275 [9]. The environs are highly congested slums with springs dominating as the prime source of water due to prohibitive costs attached to tap piped water. Unfortunately, only a few springs are properly protected with most frequently flooding in rainy seasons. Most University students end up using untreated water from the springs which are evenly distributed for drinking and other domestic purposes such as laundry and cooking. Albeit spring water having general societal receptivity, inadequate attention to solid waste management and inadequate spring protection ultimately degenerate into contamination with pathogenic bacteria of clinical significance [10]. Of the assorted ways through which water become contaminated is feacal contamination which in its entirety, is of much sincere and sound concern than other contaminants as it accounts for a variety of communicable diseases [11].

Bacteriological analysis is recommended prior to utilization of spring water especially in those suspected to be contaminated. A study in urbanite Kampala revealed that beyond $60 \%$ of the population utilizes spring water, regardless of a probable access to tap water. Regrettably, a copious percentage of the said springs are bacteriologically unsafe. Preceding investigations in and around urbanite Kampala evaluated the bacterial load of springs with no attempts to evaluate and quantize the probable risk factors enhancing microbial contamination [12]. Haruna and co-authors [12] evaluated the quality of water from protected springs in Katwe and Kisenyi parishes of urbanite Kampala. In their find- 
ings, the aggregate qualitative sanitary risk scores span from medium to high; total coliform counts in $90 \%$ of the sampled waters were above the WHO permissible limits for drinking water. On the other hand, all the water samples from the springs had faecal coliform counts well surpassing the WHO recommended limits with a strong correlation $(\mathrm{r} 2=887)$ noted between the median faecal coliform counts and the sanitary risk score. Up to $60 \%$ of the sampled spring waters registered nitrate levels surpassing the WHO permissible limit with no correlation observed between levels of chlorides and nitrates and of indicator organisms of microbial contamination.

Lukubye and Andama [13] evaluated some selected water sources in Mbarara district of Western Uganda. Of the 70 water samples drawn from boreholes, springs, wells and rainwater in Nyamitanga, Kamukuzi and Kakoba divisions, all the studied groundwater sources registered counts above WHO total coliform and E. coli permissible limits for drinking water. They concluded that the ground water sources are deleteriously unsafe for drinking without proper treatment. Interestingly, only rainwater from Mbarara University of Science and Technology fell within the WHO total coliform and E. coli permissible limits for drinking water.

Moulodi and Thorsell [14] in their project evaluated the levels of selected trace metal pollutants and physicochemical parameters in groundwater and soil from protected springs in peri-urban Kampala. All the springs indicated low metal concentrations vis-à-vis WHO permissible limits for drinking water. The soil surrounding the studied protected springs: Katalina, Bukuku and Katoogo were contaminated compared to general guidelines for East African soil. Soil from Bukuku and Katalina springs were noted to be at risk of Zinc and Cadmium contamination. Katalina spring in this study recorded the lowest electrolytic conductivity of $156 \mu \mathrm{S} / \mathrm{cm}, \mathrm{pH}$ of 5.14 and a temperature of $24.9^{\circ} \mathrm{C}$ [14]. This study reported the bacteriological and physical quality of commonly used year-round available springs in Kyambogo University vicinity.

\section{Materials and Methods}

\subsection{Apparatus and Reagents}

The chemicals used in this investigation were of high analytical purity. The assortment of volumetric glassware used in the experiment was presterilized in an autoclave at $121^{\circ} \mathrm{C}$ for 15 mins and oven dried prior to analysis.

\subsection{Sampling and Sampling Size}

The springs were selected for the study from the information provided for their demonstrated year-round permanence and included Katalina in the neighboring Banda village at the coordinates 34N459763E0038650N (Figure 1) [14] plus two other springs located in Airport (Airport springs 1 and 2), a few metres in the Western end of Kyambogo University (Figure 2 and Figure 3). Airport 1 spring is located behind Pearl Hall of Residence while Airport Spring 2 is a few meters 
away behind Uganda National Examinations Board (UNEB) offices on plot 8/13, Kyambogo road.

Two samples were taken from each spring every week for five weeks. Samples were collected between 9:00am to 10:00am (East African Standard Time) from Friday $15^{\text {th }}$ June 2018 to Friday $20^{\text {th }}$ July 2018.

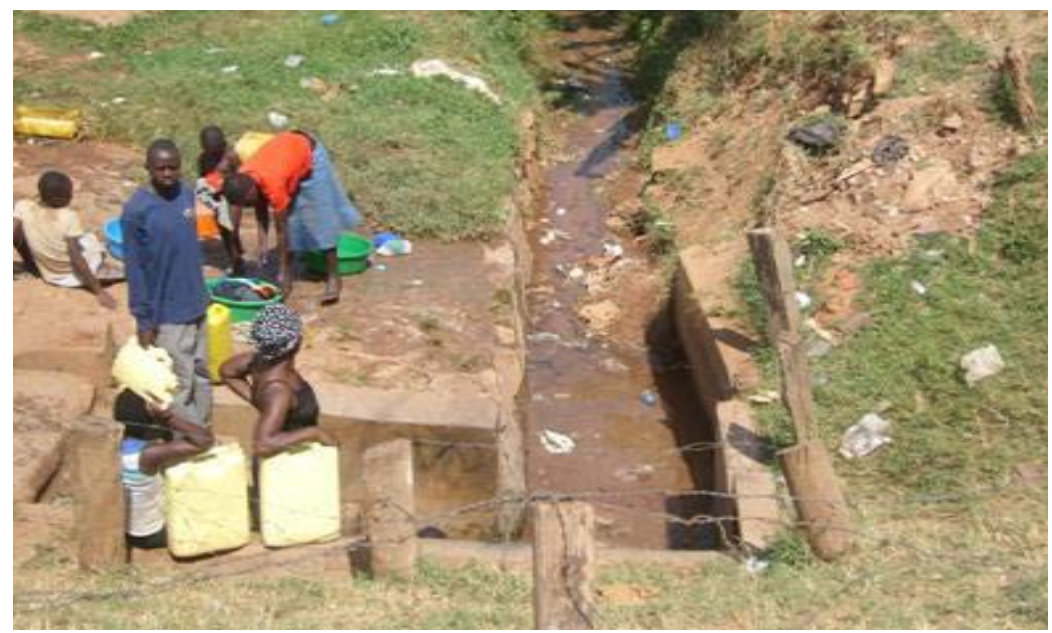

Figure 1. Katalina spring.

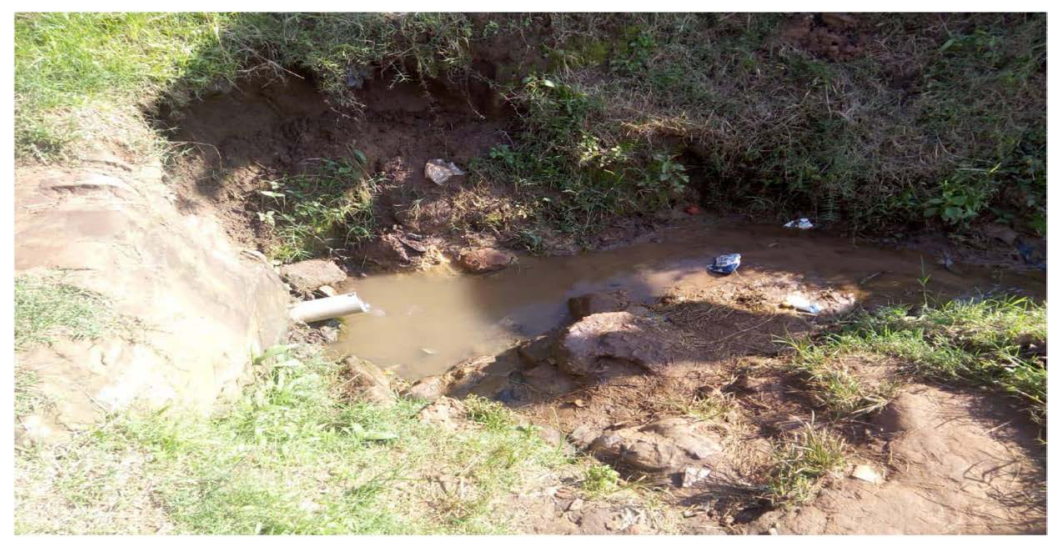

Figure 2. Airport spring 1.

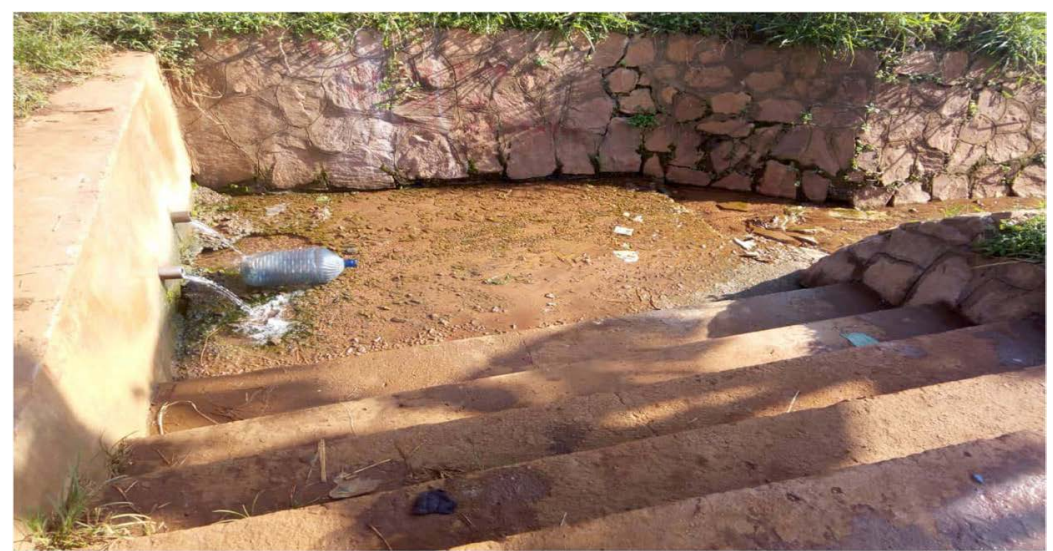

Figure 3. Airport spring 2. 
Sterilized polyethene bags from Department of Microbiology, Uganda Industrial Research Institute were used for sampling. Attachments that could cause splashing out of water at the mouth of the springs were removed and the spring water allowed to flow for one minute. With the sampling bags held at the mouth of the spring with one hand, the containers were carefully opened with the other hand and placed below the pipe and filled with water while ensuring there was air space.

\subsection{Sanitary Inspection of the Selected Springs}

A cross-sectional sanitary assessment was done in the selected springs to identify the risks for contamination with faecal bacterial organisms. The assessment followed the method of Howard [15] previously employed elsewhere [12] [13]. It entailed completion of a ten-point standardised data form with a series of questions with yes/no options for designated risks (listed under table note a of Table 1). A score of one point was awarded for each "yes" answer (risk observed) and zero point for each "no" answer (no risk observed). By way of summation of all the "yes" scores, a final risk score was obtained, which gave the overall assessment of the risk profile of each spring. The total sanitary risk score was manipulated into a percentage and the aggregate risk score graded as very high (81\% to $100 \%)$, high ( $51 \%$ to $80 \%)$, medium ( $31 \%$ to $50 \%$ ), low (1\% to $30 \%$ ) and nil $(0 \%)$ [12].

\subsection{Physicochemical Parameters}

The sampled spring water $\mathrm{pH}$ and temperatures were determined on-site using a hand held Jenway $370 \mathrm{pH} / \mathrm{mV} /$ Temperature meter (Jenway Gransmore Green, Felsted, Dunmow, Essex, CM6 3LB, England) precalibrated using pH 4, 7, 9.22 and 10 standard buffer solutions (manual override). The electrodes were thoroughly rinsed with distilled water between measurements of different water samples. Conductivity was determined on-site using a precalibrated Jenway 4520 Conductivity/TDS meter (Keison Products, Chelmsford, Essex, England).

Turbidity in Formazin Turbidity Unit (FTU) was measured using a double beam optimal geometry Genesys 10S UV-Vis spectrophotometer (Thermo Scientific, USA). Exactly $25 \mathrm{ml}$ of the sample was introduced into a sample cell and another cell was filled with distilled water. The intensity of light scattered and absorbed by the sample was compared to that measured for standard Formazin suspensions read at $850 \mathrm{~nm}$ [12].

Chloride levels were determined using the mercuric thiocyanate method as described by Haruna et al. [12]. Briefly, the sample cell was filled with $25 \mathrm{ml}$ of sample and another cell filled with an equal amount of distilled water. Exactly 2 $\mathrm{ml}$ of mercuric thiocyanate solution were added to each cell and swirled. $1 \mathrm{ml}$ of ferric ion solution was pipetted into each sample cell and swirled. The chloride concentration of the sample was measured against the blank at $450 \mathrm{~nm}$ using a spectrophotometer and reported in $\mathrm{mg} / \mathrm{L}$ of the sample. 
Table 1. Risk assessment scores of the selected springs in Kyambogo University vicinity.

\begin{tabular}{cccc}
\hline Spring & Risks Observed $^{\mathrm{a}}$ & Percentage Risk Score & Qualitative Risk Profile \\
\hline Katalina & $3,4,6,7,9,10$ & 60 & Medium \\
Airport Spring 1 & $1,2,3,4,5,6,7,9,10$ & 90 & High \\
Airport Spring 2 & $1,2,5,6,7,9,10$ & 70 & Medium \\
\hline
\end{tabular}

a. 1 = Water source unprotected; $2=$ Masonry protecting water source faulty; $3=$ Backfill area eroded; 4 = Spilt water floods collection area; $5=$ Perimeter wall absent; $6=$ Animals have access within a radius of 10 mof water source; 7 = Pit latrine uphill and/or within $30 \mathrm{~m}$ of water source; $8=$ Surface water collects upstream of water source; $9=$ Diversion ditch above water source absent $/$ non-functional; $10=$ Other pollution sources uphill of water source such as solid waste dumps, feces, stagnant water and drainage channels.

Sulphates were estimated by UV-Visible spectrophotometry as described by Swamy et al. [16]. Exactly $25 \mathrm{ml}$ of glycerol was measured into a $250 \mathrm{ml}$ beaker followed by $15 \mathrm{ml}$ of concentrated hydrochloric acid and agitated. To the beaker was added exactly $50 \mathrm{ml}$ of $95 \%$ isopropanol and agitated thoroughly. Exactly $37.5 \mathrm{~g}$ of sodium chloride was weighed and dissolved in distilled water. All the contents were mixed and made up to $250 \mathrm{ml}$ with distilled water. This solution was marked as the conditioning reagent. The standards for sulphate was prepared by weighing $1.479 \mathrm{~g}$ of anhydrous sodium sulphate and dissolving it in distilled water to make $1 \mathrm{~L}$, equivalent to $1000 \mathrm{ppm}$ sulphate $(1 \mathrm{ml}=1.0 \mathrm{mg}$ $\mathrm{SO}_{4}^{2-}$ ). Exactly $10 \mathrm{ml}$ of standard Sulphate solution was measured to the first flask, $20 \mathrm{ml}$ to the second, $30 \mathrm{ml}$ to the third, $40 \mathrm{ml}$ to the fourth, and $50 \mathrm{ml}$ to the fifth flask. To the sixth flask was added distilled water alone and labeled as blank. All the six flasks were topped to the $100 \mathrm{ml}$ mark of volumetric flask using distilled water and capped. The samples were prepared by pipetting $10 \mathrm{ml}$ of each sample into a $25 \mathrm{ml}$ flask. $5 \mathrm{ml}$ of the conditioning reagent was added independently to each sample and the standards after every 3 minutes. The analysis was done at $420 \mathrm{~nm}$ using a double beam optimal geometry Genesys $10 \mathrm{~S}$ UV-Vis spectrophotometer (Thermo Scientific, USA).

\subsection{Bacteriological Analysis}

The working table was disinfected using $70 \%$ ethanol. McConkey culture media was prepared following standard guidelines in the Bacteriological Analytical Manual (BAM) and the ISO test method according to the manufacturer's instructions. Exactly $35.0 \mathrm{~g}$ of the McConkey powder (Conda) was dissolved in 1 litre of distilled water to make a single strength McConkey broth. Another $70.0 \mathrm{~g}$ of the McConkey powder (Conda) was dissolved in 1 litre of distilled water to make a double strength McConkey broth. Buffered peptone water was prepared by weighing $20.0 \mathrm{~g}$ of peptone (Conda) powder and dissolving it in 1 liter of distilled water. Levine Eosin Methylene broth (LEMB) was prepared by weighing $20.0 \mathrm{~g}$ of Levine Eosin Methylene Brothpowder (Oxoid, UK) and dissolving it in 1 liter of distilled water. The prepared media and solution were then covered with cotton wool, wrapped in an Aluminium foil (Hotpack, Kampala) and autoclaved at $121^{\circ} \mathrm{C}$ for 15 minutes. The Levine Eosin Methylene broth was cooled 
in a water bath maintained at $60^{\circ} \mathrm{C}$ before they were finally poured into sterile petri dishes and allowed to set.

The multiple tube method was used to determine and enumerate the levels of total coliforms in the samples. It was divided into three tests; that were the presumptive test, confirmatory and completed tests and each test exploited one or more of the characteristics of the coliforms.

Serial dilutions from one to five-fold $\left(10^{1}\right.$ to $\left.10^{5}\right)$ dilutions were aseptically prepared using a ten-fold dilution series. Exactly $10 \mathrm{ml}$ of the water samples were pipetted into the McConkey tubes containing $1 \mathrm{ml}$ of double strength McConkey broth while $0.1 \mathrm{ml}$ of the water samples were added to the McConkey tubes containing $10 \mathrm{ml}$ of single strength McConkey broth. In all the McConkey tubes, the inverted vials (sterile Durham tubes) were inserted to trap the gas that would be produced and incubated at $37^{\circ} \mathrm{C}$ for 48 hours. The presence of the coliforms was indicated by turbidity, gas production and $\mathrm{pH}$ change due to fermentation of lactose and the change of color in the tubes. The Most Probable Number (MPN) index was determined by comparing the partner of the positive results with MPN statistical table and the results were reported per $100 \mathrm{ml}$ of the sample.

The positive tubes were confirmed by streaking the plates on Levine Eosin Methylated agar and incubating at $35^{\circ} \mathrm{C}$ for 24 hours. Colonies that had dark centers with green metallic sheen were counted and confirmed positive of coliforms.

After the presumptive test, sub-cultures were made from all the tubes showing acid and gas to fresh tubes of single strength McConkey medium. The test tubes were then incubated at $44^{\circ} \mathrm{C}$ and examined after 48 hours. All the tubes that showed gas production were counted and confirmed to be positive for fecal coliform and the MPN was calculated using the MPN statistical table. Since not all thermotolerant (fecal) coliforms are E. coli, a loopful from all the positive tubes in LEMB were inoculated in $5 \mathrm{ml}$ of buffered peptone water and incubated at $35^{\circ} \mathrm{C}$ for 24 hours. The formation of Indole (red color ring) on addition of 0.1 $\mathrm{ml}$ of Kovacs reagent indicated the presence of $E$. coli. The results were compared using the MPN table statistically and reported as CFU/100ml of the sample.

\subsection{Statistical Analysis of Results}

Results from the experimental work were analyzed basing on the WHO guidelines for drinking water [17]. The results were subjected to statistical analysis using Minitab statistical software (v18, Minitab Inc, USA). Descriptive statistics of triplicate analyses of the faecal coliform and $E$. coli counts of the water samples was done followed by a One-Way Analysis of Variance for the mean differences of the total coliforms and $E$. coli counts.

\section{Results and Discussion}

\subsection{Sanitary Risk Assessment}

Sanitary inspection of water sources is a pivotal analytical asset for the evalua- 
tion of the risks of microbial vitiation of water sources including spring water [12] [13] [15]. It is a fundamental asset for the identification of the probable causes of contamination, risk of future contamination and overall assessment of operation and maintenance of water supplies [12] [13] [15]. The sanitary risk assessment of the selected springs in the study area is given in Table 1.

All the springs studied faced at least more than four risks of microbial contamination. The qualitative aggregate risk scores ranged from medium to high; with the highest score of $90 \%$ from Airport 1 spring whereas Katalina and Airport 2 springs had medium scores of $60 \%$ and $70 \%$ respectively. No spring had a low ( $1 \%$ to $30 \%)$ or no $(0 \%)$ risk score. The common risks identified in the studied springs included total absence of spring protection, faulty masonry protecting the spring, eroded backfill area, flooding of spilt water at collection area, total absence of perimeter fence, ability of animals to access the spring within a radius of $10 \mathrm{~m}$ from the water source, presence of pit-latrines uphill and/or within $30 \mathrm{~m}$ radius from the spring, non-functional and/or total absence of the diversion ditch above water source and other pollution sources uphill of the springs such as solid waste dumps, faeces, stagnant water and drainage channels. Sanitary risk assessment of the springs revealed that Airport spring 1 had a high bacterial contamination risk; Katalina and Airport spring 2 had medium contamination risk. Both Katalina and Airport spring 2 posed medium risks of bacterial contamination comparable to that of Kasule, Maama Betty and Bwanika I springs in Katwe and Kisenyi parishes of Metropolitan Kampala reported by Haruna and co-authors [12] and springs in Kiswahili and Kisenyi, Mbarara Municipality reported by Lukubye and Andama [13].

\subsection{Physicochemical Profile of the Springs}

The physicochemical parameters determined for the selected springs are given in Table 2.

Katalina water had a mean temperature of $20.53^{\circ} \mathrm{C} \pm 1.23^{\circ} \mathrm{C}$, Airport 1 spring had a mean temperature of $21.53^{\circ} \mathrm{C} \pm 0.60^{\circ} \mathrm{C}$ while Airport 2 spring had a temperature of $20.33^{\circ} \mathrm{C} \pm 1.62^{\circ} \mathrm{C}$ (Table 2). There was no statistically significant difference $(\mathrm{p}<0.05)$ in the temperatures of the springs. The temperature obtained for Katalina spring is lower than that reported by Muolodi and Thorsell [14]. This could be because it was a wet season with much torrential rains thus lower temperatures than that recorded in the dry season by Muolodi and Thorsell. The $\mathrm{pH}$ recorded in the springs were $5.33 \pm 0.25,6.30 \pm 0.10$ and $7.10 \pm 0.46$ for Katalina, Airport spring 1 and Airport spring 2 respectively. The $\mathrm{pH}$ value of Airport spring 2 was within the acceptable limits for drinking water standards of WHO (6.5 - 8.5) [17]. The $\mathrm{pH}$ value for Katalina was slightly higher than 5.14 reported by Muolodi and Thorsell [14]. This could be attributed to heavy down pours that could have carried acidic materials downstream that infiltrated into the ground water. The slightly acidic $\mathrm{pH}$ for Katalina and Airport spring 2 could be due to carbon dioxide saturation in the ground water [12] [18], corroborant 
Table 2. Physicochemical profile of the selected springs in Kyambogo University vicinity.

\begin{tabular}{ccccccc}
\hline Spring & $\begin{array}{c}\text { Temperature } \\
\left({ }^{\circ} \mathrm{C}\right)\end{array}$ & $\mathrm{pH}$ & $\begin{array}{c}\mathrm{E} . \mathrm{C} \\
(\mu \mathrm{S} / \mathrm{cm})\end{array}$ & $\begin{array}{c}\text { Turbidity } \\
(\mathrm{FTU})\end{array}$ & $\begin{array}{c}\mathrm{Cl}^{-} \\
(\mathrm{mg} / \mathrm{L})\end{array}$ & $\begin{array}{c}\mathrm{SO}_{4}^{2-} \\
(\mathrm{mg} / \mathrm{L})\end{array}$ \\
\hline Katalina & $20.53 \pm 1.23$ & $5.33 \pm 0.25$ & 162 & $<5$ & $6.63 \pm 0.20$ & $2.44 \pm 0.05$ \\
Airport Spring 1 & $21.53 \pm 0.60$ & $6.30 \pm 0.10$ & 201 & $<5$ & $10.91 \pm 0.50$ & $5.31 \pm 0.24$ \\
Airport Spring 2 & $20.33 \pm 1.62$ & $7.10 \pm 0.46$ & 158 & $<5$ & $9.24 \pm 0.07$ & $3.99 \pm 0.11$ \\
\hline
\end{tabular}

with the results of other springs around Urbanite Kampala investigated by other authors [12] [14] [19]. Consuming excessively acidic or alkaline water is harmful to the body. Drinking water must have a $\mathrm{pH}$ value in the range of $6.5-8.5$ [17]. It is further noted that even within the acceptable $\mathrm{pH}$ range, slightly high or low $\mathrm{pH}$ values of water can be unpleasant for several reasons. High $\mathrm{pH}$ causes water to have a slippery feel, tastes like baking soda. Low $\mathrm{pH}$ water on the other hand may have a bitter taste or metallic taste and may lead to fixture corrosion. The presence of sulphates and chlorides in spring water is associated with fecal contamination from wastewater. Chloride levels were $6.63 \pm 0.20,10.91 \pm 0.50$ and $9.24 \pm 0.07 \mathrm{mg} / \mathrm{L}$ for Katalina, Airport 1 and Airport 2 springs. All water samples had chloride levels below WHO acceptable level of $250 \mathrm{mg} / \mathrm{L}$. The levels of sulphates observed in this study were low and could probably be attributed to poor sanitation, and thus leaching of sulphates from nearby pit latrines. The sulphate content in water is important in determining the suitability of water for public and industrial use. Sulphate may also contribute to the corrosion of pipelines in the distribution system [20]. According to WHO, typical sulfate levels in fresh spring water are in the vicinity of $20 \mathrm{mg} / \mathrm{L}$ and range from $0-630 \mathrm{mg} / \mathrm{L}$ in rivers [21]. High doses of sulphate particularly magnesium sulphates, cause catharsis or purging of the bowels, and magnesium sulphate has been used as a purgative [22]. The taste thresholds of sulphates are $200-500 \mathrm{mg} / \mathrm{L}$ for sodium, $250 \mathrm{mg} / \mathrm{L}$ for calcium and $400-600 \mathrm{mg} / \mathrm{L}$ for Magnesium [23]. Electrical conductivity (EC) ranged from $162-201 \mu \mathrm{S} / \mathrm{cm}$. The electrical conductivity of water estimates the total amount of solids dissolved in the water (the water's total dissolved solids). For water, it depends on the water's temperature; the higher the temperature, the higher the electrical conductivity and vice versa. This ability is directly related to the concentration of ions in the water, and this is supported by the levels of chlorides and sulphates registered in this study. All samples had turbidity levels within WHO permissible level of less than 5 FTU. In drinking water, turbidity more than 5 TFU indicate the presence of high bacteria levels, pathogens or particles that can shelter harmful organisms from disinfection processes.

\subsection{Microbiological Profile of the Springs}

The microbiological profile of the springs is given in Table 3. The median microbiological counts recorded in this study are corroborant with preceding results of other areas of urbanite Kampala reported by Haruna et al. [12], Taylor 
Table 3. Microbiological profile of the selected springs in Kyambogo University vicinity.

\begin{tabular}{ccccc}
\hline \multicolumn{2}{c}{ Parameter (CFU/100ml) } & Katalina $(\mathrm{n}=10)$ & Airport $1(\mathrm{n}=10)$ & Airport 2 $(\mathrm{n}=10)$ \\
\hline \multirow{4}{*}{ Total coliform } & Mean & $28.7 \pm 0.82$ & $47.4 \pm 1.13$ & $34.5 \pm 2.92$ \\
& Median & 36.4 & 46.9 & 29.4 \\
& Range & $27.1-29.7$ & $45.8-59.6$ & $28.8-38.4$ \\
& S.D & 1.422 & 1.955 & 5.065 \\
& Mean & $2.77 \pm 0.18$ & $4.57 \pm 0.37$ & $4.10 \pm 0.55$ \\
E. coli & Median & 2.7 & 4.2 & 4.2 \\
& Range & $0-5$ & $0-8$ & $0-6$ \\
& S.D & 0.306 & 0.635 & 0.954 \\
\hline
\end{tabular}

b.S.D-Standard deviation, Mean is presented as Mean \pm Standard Error.

and Howard [24] and Barret et al. [25]. The presence of the indicator organisms of fecal contamination is indicative of sewage contamination of these springs. There was a significant difference $(p<0.05)$ in the $E$. coli count in Katalina and Airport spring 1. A significant difference was also observed in the total coliform count of Katalina and Airport spring $1(p<0.05)$ and Airport Spring 1 and Airport spring $2(p<0.05)$. The elevated counts of $E$. coli and total coliforms could be because of the heavy down pours experienced in the study period [24] [25]. This could have been accentuated by sub-surface infiltration, a phenomenon reported to coincide with torrential down pours [26] [27]. Katalina spring has the nearest household at $5 \mathrm{~m}$ from the spring with plenty of houses both upstream and downstream of the spring [14]. Another factor is the lack of diversion ditches which in turn permits surface runoff to flow onto the backfill area which could have increased the level of contamination [15]. The high microbial load may also be attributed to sub-surface leaching from pit latrines as well as direct washing of faecal material in to the springs [12]. Overall, the trend of $E$. coli in the springs meets the Uganda National Bureau of Standards (UNBS) water quality guidelines of $73 \%$ for spring water [13] [28]. The differences in the counts of $E$. coli and the total coliforms in the studied springs can be attributed to the differences in the various microbial contamination risks observed in the springs (Table 1) [13].

\section{Conclusion}

The water samples from the springs had elevated levels of total coliforms and $E$. coli. The $\mathrm{pH}$ of the water from Airport 2 spring is within the acceptable limits of 6.5 - 8.5 while that of Katalina and Airport spring 1 are slightly acidic. The temperature of the water from the springs are normal. Water from the springs in Kyambogo University vicinity are microbiologically not safe for drinking and should be boiled or treated before drinking. Drainage ditches should be constructed uphill of the springs to divert torrential flowing rain water which carry contaminants washed from Kyambogo hill. Fences should be constructed 
around the springs to keep away animals which destroy the retaining spring walls predisposing them to factors of contamination or directly contaminate water by defecating at the collection points. Government should provide safe drinking water sources through provision of boreholes and community piped water. Government should allocate funds for periodic testing of these water sources in the local communities to monitor and check their bacteriological quality and provide water treatment drugs like water guard and aqua safe to the community households. Research should be done to ascertain the correlation between the clinical status of the community and contamination of the springs. Other underground water sources in the vicinity should be analyzed for their physicochemical and microbial qualities.

\section{Acknowledgements}

We would love to convey our hearty thanks to the staff of Microbiology Department, Uganda Industrial Research Institute, Kampala for the services accorded to us towards the analytical success of this research.

\section{Conflicts of Interest}

The authors declare no conflicts of interest regarding the publication of this paper.

\section{References}

[1] Mellisa, B. (2018) UN Water Day. 36-Eye Opening Facts about Water. https://www.treehugger.com/clean-water/36-eye-opening-facts-about-water.html

[2] Hughes, J.M. and Koplan, J.P. (2005) Saving Lives through Global Safe Water. Emerging Infectious Diseases, 11, 1636-1637. https://doi.org/10.3201/eid1110.051099

[3] World Health Organization, WHO (2008) Guidelines for Drinking-Water Quality: Recommendations, Vol. 1 of Incorporating First and Second Addenda. 3rd Edition, World Health Organization, Geneva.

[4] Bordalo, A. and Machado, A. (2014) Water Bags as a Potential Vehicle for Transmitting Disease in a West African Capital, Bissau. International Health, 7, 42-48. https://doi.org/10.1093/inthealth/ihu056

[5] Warburton, D.W. (2000) The Microbiological Safety of Bottled Waters in Safe Handling of Foods. Farber, J.M. and Ewen, E.D., Eds., Marcel Dekker, New York.

[6] Mavridou, A. (1992) Study of the Bacterial Flora of a Non-Carbonated Natural Mineral Water. Journal of Applied Bacteriology, 73, 355-361. https://doi.org/10.1111/j.1365-2672.1992.tb04989.x

[7] Blake, M.L.R., Florencia, J., Costa, J.B., do Prado Quintino, L. and Gangarosa, E.J. (1977) Cholera in Portugal, 1974. II. Transmission by Bottled Mineral Water. American Journal of Epidemiology, 105, 344-348. https://doi.org/10.1093/oxfordjournals.aje.a112392

[8] Globefeed.com (2018) Road Distance between Central Kampala and Kyambogo with Distance Indicator.

$\underline{\text { https://distancecalculator.globefeed.com/Uganda_Distance_Result.asp?fromplace=Kampal }}$ 
a\%20()\%20\&toplace=Kyambogo\%20(Western\%20Province)\%20\&fromlat=0.3155556\&tol at $=0.3502778 \&$ fromlng $=32.5655556 \&$ tolng $=32.6308333$

[9] Google (2018) Location of Kyambogo at Google Maps. https://www.google.com/maps/place/0\%C2\%B020'54.0\%22N+32\%C2\%B037'49.0\%2 2E/@0.3496984,32.6333348,16z/data=!4m5!3m4!1s0x0:0x0!8m2!3d0.3483333!4d 32.6 302778

[10] Robillard, P.D., Sharpe, W.E. and Wistock, B.R. (2003) Nitrates in Drinking Water. Pennsylvania State University, Agricultural and Biological Engineering.

[11] James, G.V. (1971) Water Treatment. 4th Edition, Technical Press, Edinburgh.

[12] Haruna, R., Ejobi, F. and Kabagambe, E.K. (2005) The Quality of Water from Protected Springs in Katwe and Kisenyi Parishes, Kampala City, Uganda. African Health Sciences, 5, 14-20.

[13] Lukubye, B. and Andama, M. (2017) Bacterial Analysis of Selected Drinking Water Sources in Mbarara Municipality, Uganda. Journal of Water Resource and Protection, 9, 999-1013. https://doi.org/10.4236/jwarp.2017.98066

[14] Moulodi, S. and Thorsell, J. (2013) Evaluation of the Levels of Selected Trace Metal Pollutants in Groundwater and Soil from Protected Springs in Peri-Urban Kampala, Uganda. Masters Dissertation. TRITA-LWR Degree Project 13: 17. Royal Institute of Technology (KTH), $56 \mathrm{p}$.

[15] Howard, A.G. (2002) Water Supply Surveillance: A Reference Manual. WEDC, Loughborough University.

[16] Kipngetich, T.E., Magut, H. and Swamy, T.A. (2013) Determination of Levels of Phosphates and Sulphates in Domestic Water from Three Selected Springs in Nandi County, Kenya. International Journal of Pharmaceutical and Life Sciences, 4, 2828-2833.

[17] WHO, World Health Organization (1997) Guidelines for Drinking Water Quality, Vol. 3: Surveillance and Control of Community Water Supplies. 2nd Edition, World Health Organisation, Geneva.

[18] Byamukama, D., Kansime, F., Mach, I.R. and Farnleitner, A. (1999) Determination of Escherichiacoli Contamination with Chromocult Coliform Agar Showed a High Level of Discrimination Efficiency for Differing Pollution Levels in Tropical Waters of Kampala, Uganda. Applied and Environmental Microbiology, 66, 864-868. https://doi.org/10.1128/AEM.66.2.864-868.2000

[19] Nshekanabo, N. and Wozei, E. (1997) Spring Water Quality Improvement in Slums. Sanitation and Water for All. Proceedings of 24 th WEDC Conference, Islamabad, 264-266. http://wedc.lboro.ac.uk/resources/conference/24/Nshekana.pdf

[20] Mariraj, M.S.L. and Vanalakshmi, P. (2013) Assessment of Water Quality in Noyyal River through Water Quality Index. International Journal of Water Resources and Environmental Engineering, 5, 35-48.

[21] World Health Organization, WHO (2004).Guidelines for Drinking Water Quality. Vol. 1, 3rd Edition, World Health Organization, Geneva.

[22] Cocchetto, D.M. and Levy, G. (1981) Absorption of Orally Administered Sodium Sulphate in Human. Journal of Pharmaceutical Sciences, 70, 331. https://doi.org/10.1002/jps.2600700330

[23] Zoeteman, B.C.J. (1980) Sensory Assessment of Water Quality. Pergamon Press, New York.

[24] Taylor, R.G. and Howard, A.G. (1995) Groundwater Quality in Rural Uganda: Hydrochemical Considerations for the Development of Aquifers within the Basement 
Complex of Africa. In: McCall, J. and Nash, H., Eds., Groundwater Quality, Chapman and Hall, London, 31-43.

[25] Barrett, M.H., Nalubega, M., Howard, A.G., Taylor, R.G. and Pedley, S. (1999) The Impact of On-Site Sanitation on Urban Groundwater Quality in Uganda. In: Fendecova and Fendek, Eds., Hydrogeology and Land Use Management, IAH, Bratislava, 335-340.

[26] Howard, G., Pedley, S., Barett, M., Nalubega, M. and Johal, K. (2003) Risk Factors Contributing to Microbiological Contamination of Shallow Groundwater in Kampala, Uganda. Water Research, 37, 3421-3429.

https://doi.org/10.1016/S0043-1354(03)00235-5

[27] Nsubuga, F.B., Kansiime, F. and Okot, O.J. (2004) Pollution of Protected Springs in Relation to High and Low Density Settlements in Kampala, Uganda. Physics and Chemistry of the Earth, 29, 1153-1159. https://doi.org/10.1016/j.pce.2004.09.001

[28] Nabucha, A. and Rugumayo, A.I. (2015) Water Quality Assessment in a Rural Setting: A Case Study of Budaka District. UNESCO International Scientific Symposium, Kyoto-Otsu, 15-18 July 2015, 1-4.

http://www.unescokyotosympo2015.org/abstracts/Rugumayo\%20-\%20Water\%20Q uality\%20Assessment\%20in\%20a\%20Rural\%20Setting.pdf 